\author{
Revista Minelor - Mining Revue \\ ISSN-L 1220-2053 / ISSN 2247-8590 \\ vol. 27, issue 2 / 2021, pp. 14-29
}

\title{
MONITORING AND FORECASTING OF SURFACE DEFORMATION AT VICTORIA AND CANTACUZINO MINES
}

\author{
Ilie ONICA ${ }^{1}$, Dacian-Paul MARIAN ${ }^{2}$, Ovidiu MARINA ${ }^{3}$ \\ ${ }^{1}$ University of Petroșani, Petroșani, Romania, onicai2004@yahoo.com \\ ${ }^{2}$ University of Petroșani, Petroșani, Romania, dacianmarian@upet.ro \\ ${ }^{3}$ SNS Bucharest, Slănic-Prahova Branch, Romania, marina.ovidiu1970@yahoo.com
}

DOI: $10.2478 / \operatorname{minrv}-2021-0013$

\begin{abstract}
The underground mining of the rock salt deposit from Slănic started in 1665, with the Old Mines and continued in 1970, with Victoria Mine, then in 1993, with Cantacuzino Mine. The mining method applied at Victoria and Cantacuzino mines was the one with small rooms and square pillars, with which over 9.7 million $m 3$ of rock salt were extracted. This very large volume of underground mining voids led to the convergence of the underground excavations and thus to the deformation of the surface. This article presents the analysis of the measurements of surface displacement and the prediction of its subsidence over time. Also, the main factors that contributed to the deformation of the surface are analyzed, namely: the dimensions of the underground voids, the mining depth, the geomechanical characteristics, the tectonics and microtectonics of the deposit, the hydrogeology and the effect of blasting.
\end{abstract}

Keywords: rock salt, deformation, subsidence, rooms, square pillars, ceilings, monitoring, prognosis

\section{The evolution of the underground mining of the rock salt deposit from Slănic}

The underground mining of the rock salt deposit from Slănic began between 1665-1865 with the help of bell-type rooms and continued with the extraction in large trapezoidal rooms in the Old Mines (Systematica 1865-1875; Principatele Unite Mine or Carol, between 1831-1935; Mine 23 August or Mihai, between 1912-1943; Unirea Mine, in the period 1947-1971), from where a volume of over 5.5 million $\mathrm{m}^{3}$ of rock salt was extracted.

In 1970, Victoria Mine was opened, where the small rooms and square pillars mining method was applied, with multi-storey levels, separated by safety ceilings with a thickness of $8 \mathrm{~m}$. The itercameral pillars with the horizontal square section, with a side of 14-17.5 m and a height of $8 \mathrm{~m}$, are arranged coaxially, on all the 11 levels of the mine. The mining rooms have a horizontal square surface, with a side of $16-12.5 \mathrm{~m}$ and a height of $8 \mathrm{~m}$. Due to safety and security considerations in operation, the activity of the Victoria mine was stopped in 1992. At this mine, the voids resulted from the underground mining of the deposit amount to an area of $922391 \mathrm{~m}^{2}$ and a volume of $7379128 \mathrm{~m}^{3}$.

Starting with 1993, south of the old mines, Cantacuzino Mine was opened, where the mining method with small rooms, square pillars and a straight ceiling was applied between the levels V and VII, and starting from level VIII, the same method was applied, but with rooms with vaulted ceilings. The dimensions of the pillars increased with the depth, as follows: for levels V - VII, $L_{p}=16 \mathrm{~m}$; for levels VIII - X, $L_{p}=17 \mathrm{~m}$; for level XI, $L_{p}=18 \mathrm{~m}$. Until 1999, a volume of rock salt of approx. $2362324 \mathrm{~m}^{3}$ was extracted from Cantacuzino mine.

As the exploitable reserves at Cantacuzino Mine, located above the level $+200 \mathrm{~m}$, have been depleted, the activity continues below the level $+200 \mathrm{~m}$, starting with the XIV-th level, located under an equalization ceiling. This ceiling is established under Cantacuzino Mine (elevation $+193 \mathrm{~m}$ ), under Unirea and Principatele Unite Mine (elevation $+188 \mathrm{~m}$ ) and under Victoria Mine (elevation $+193 \mathrm{~m}$ ), up to elevation $+153 \mathrm{~m}$. The $14^{\text {th }}$ floor is located between elevation $+153 \mathrm{~m}$ and elevation $+145 \mathrm{~m}$, below the leveling ceiling. Here, the same mining method with small rooms, square pillars and vaulted ceiling is applied, with the following dimensions of the

\footnotetext{
* Corresponding author: Dacian-Paul Marian, Assoc.Prof. PhD. Eng., University of Petroșani, Petroșani, Romania, contact details (University st. no. 20, Petroșani, Romania dacianmarian@upet.ro)
} 
pillars: $L_{p}=18 \mathrm{~m}$, in the area located west of the alignment of pillars $\mathrm{K} 5-\mathrm{K} 47 ; L_{p}=19 \mathrm{~m}$, in the area located east of the alignment of pillars K5 - K47.

\section{General information on surface subsidence in the area of influence of Victoria and Cantacuzino Mines}

Following the extraction of a volume of useful mineral substances from a deposit (in our case, rock salt) the state of stresses and deformations in the massif changes, having the effect of destroying the stability of the surrounding rocks [1]. Under certain conditions, the deformation of the massif can propagate to the surface, causing surface subsidence. Depending on its manifestation, subsidence can be continuous or discontinuous.

Discontinuous subsidence is characterized by significant surface displacements, above the exploited deposit area, and the formation of discontinuities in the surface profile. These can be specific to some mining methods, which trigger a series of mechanisms that can develop suddenly or progressively and can manifest themselves at different scales.

In the conditions of underground mining of the rock salt deposit from Slănic Prahova, it can be defined as a discontinuous subsidence or deformation of the land, the collapse of the rocks after a sinkhole near the Carol shaft, due to the dissolution voids appeared on the rock salt ridge. Also, in this category can be included the collapse of the bell-type rooms, as a result of the collapse of the safety ceiling, which led to the formation of surface pits, respectively salt lakes Baia Verde, Baia Baciului, Lacul Mare, Grota Miresei and Baia Porcilor. And in general, all dissolution voids can lead to the sudden dislocation of rocks after such sinkholes.

The category of continuous subsidence or actual subsidence includes those deformations of the surface that form an extended profile of the subsidence trough and that expand progressively, with the expansion of the underground mining surface. The displacements of the points from the surface, in comparison with the dimensions of the subsidence area or the mining depth are, in order of magnitude, within the limits of elasticity of the geological formations. This type of subsidence is characteristic of seams or veins of low or medium thickness, horizontal or slightly inclined, contained in weak rocks or plastic sedimentary rocks. They also result from the underground mining of the coal seams by longwall mining method or the extraction of other deposits of useful mineral substances, such as sulfur or evaporite deposits, deposited in sedimentary deposits - as is the case with rock salt deposits [2].

According to Brauner [3], continuous subsidence occurs at each point of the subsidence trough, being characterized by five important parameters: vertical subsidence, inclination and curvature of the subsidence trough and the horizontal deformations of compression and traction $[4,5]$. Each influencing factor induces different types of surface destruction (figure 1).

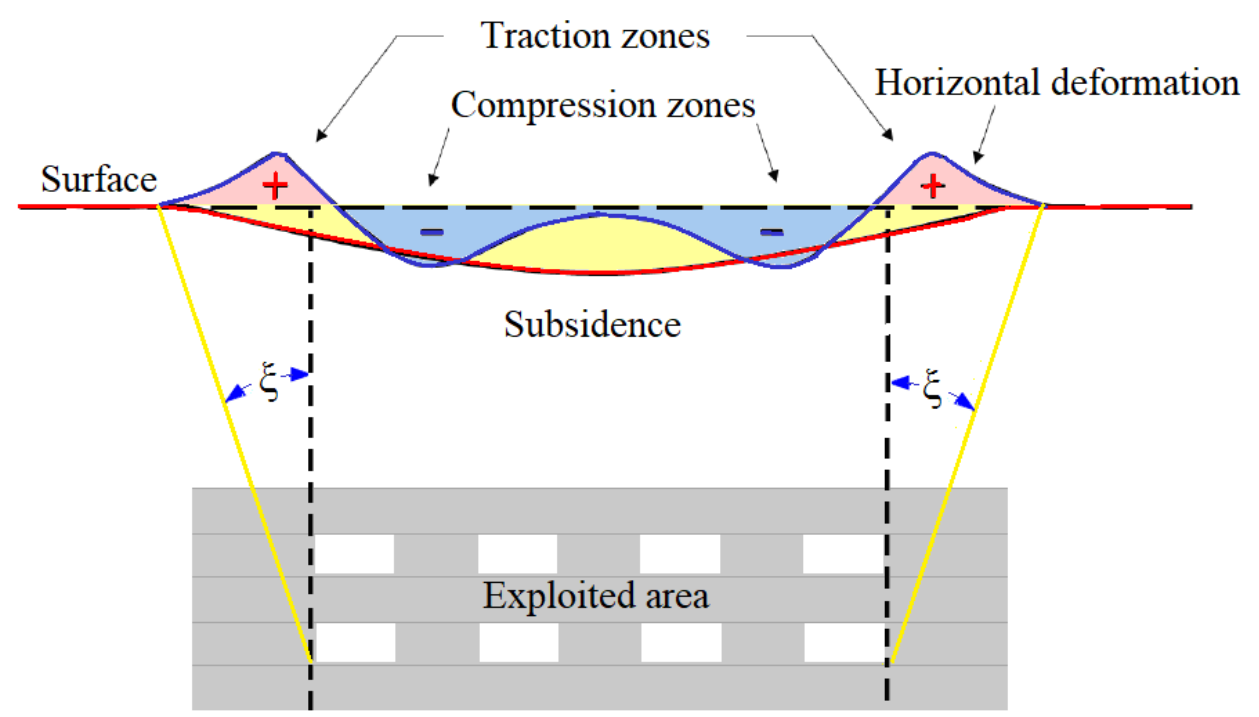

Fig. 1. Influence of the underground mining of rock salt deposits on the surface (modified after [6])

The area of influence of the underground excavations is delimited from the stable area by some planes, inclined towards the vertical with the angles of influence (figure 1). The subsidence angles $\beta, \gamma$ and $\delta$, in ${ }^{\circ}$, are the angles between the subsidence planes or between the boundaries of the area of influence upstream, downstream and in the direction of the exploited area, and horizontal. In the case of rock salt deposits these 
angles are equal to each other and are complementary to the angle of influence (limit angle): $\beta=90^{\circ}-\xi$. For the geo-mining conditions from Slănic salt mine, the following values of the subsidence and influence angles were used: for the rock salt massif: $\beta=60^{\circ} ; \xi=\xi^{\prime}=30^{\circ}$; for the surrounding rocks: $\beta=45^{\circ}$; $\xi=\xi^{\prime}=45^{\circ}$. These values were used to delimit the areas of influence of the exploitation of the deposit and to draw the main safety pillars.

Analyzing the scalar graphical representations of the total displacements in figure 2, it can be seen that the limit planes of influence, inclined with subsidence angles of $60^{\circ}$, for the rock salt massif and $45^{\circ}$, for the surrounding rocks, very well frame the areas of influence of underground excavations, where rock movements are observed. These values validate both the results obtained by numerical modeling [7] and the angles adopted from field observations and used to design the main safety pillars and areas of influence of underground mining excavations.

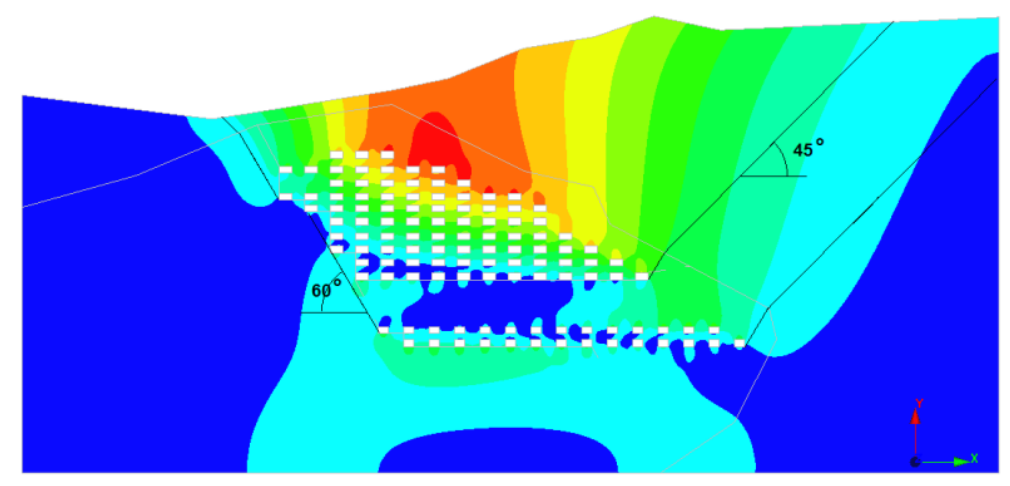

a)

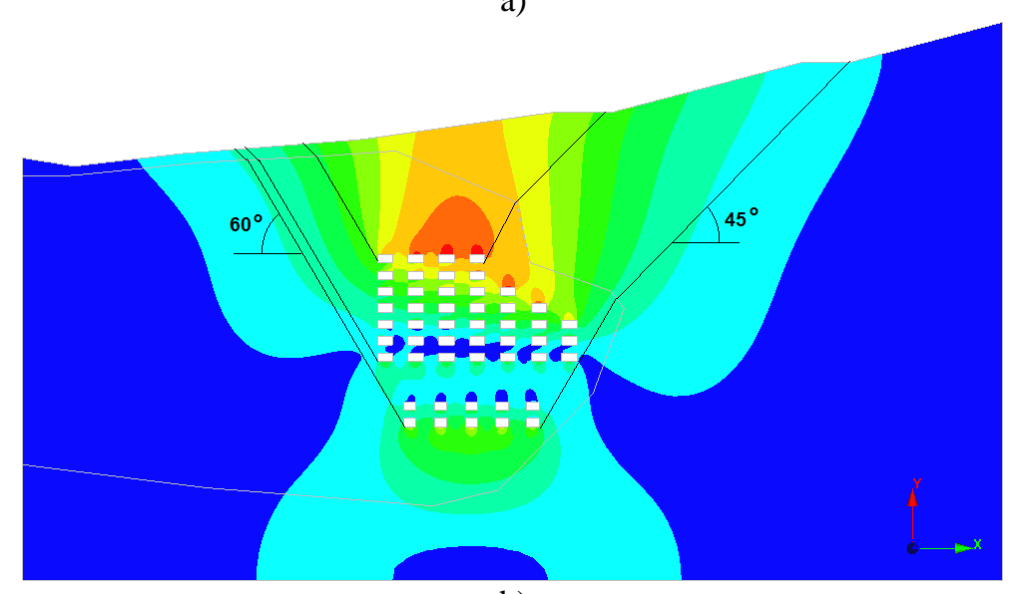

b)

Fig. 2. The correlation between the scalar distribution of the total displacement norm and the subsidence angles (future situation, after the extraction of the levels $+145 \mathrm{~m}$ and $+129 \mathrm{~m}$, from Mina Nouă Slănic)

for some representative cross sections through the mines: a) Victoria; b) Cantacuzino

In the case of a body of salt, such as the one at Slănic Prahova salt mine, the development of the subsidence trough occurs both after the excavated surface of the level, and especially after the development of the excavation in depth, which can be seen in figure 2 .

If in other cases of underground mining (by directing the mining pressure by the collapse of the surrounding rocks or the collapse of the useful minerals and the surrounding rock or even in the case of total backfilling of the extracted area), the geomechanical phenomenon of the appearance of the subsidence trough at the surface is obviously continuous, in the case of underground mining with rooms and pillars, the phenomenon of surface deformation is less pronounced and explainable only by the convergence of the excavations left after mining. This is the case of Cantacuzino mine, mined with small rooms and square pillars (on a network of $30 \times 30 \mathrm{~m}$ ), in levels (sub-levels) of $16 \mathrm{~m}$, where the phenomenon of surface deformation is an evolutionary one, over a long period of time (between 1992 and 2020).

After the underground mining of the $5^{\text {th }}$ level began, following the change of the natural state of stresses and deformations, there were vertical deformations of the pillars, within their elastic limits, and reduced subsidence of the ceiling of the rooms, which were then transmitted to the protection ceiling, from the ridge of 
salt and further into the overlying rocks. Due to the low deformations of the pillars, their vertical displacements were taken over by the expansion/dilation capacity of the rock salt and the covering rocks, and the surface deformation was of the order of tens of millimeters, in a subsidence trough with a certain extension produced in 1994. The exploitation of the deposit followed, level by level, until the complete extraction of the XI floor, when the subsidence trough reached its maximum extension, for a total extraction height of the deposit of 104m (figures 3, 4).

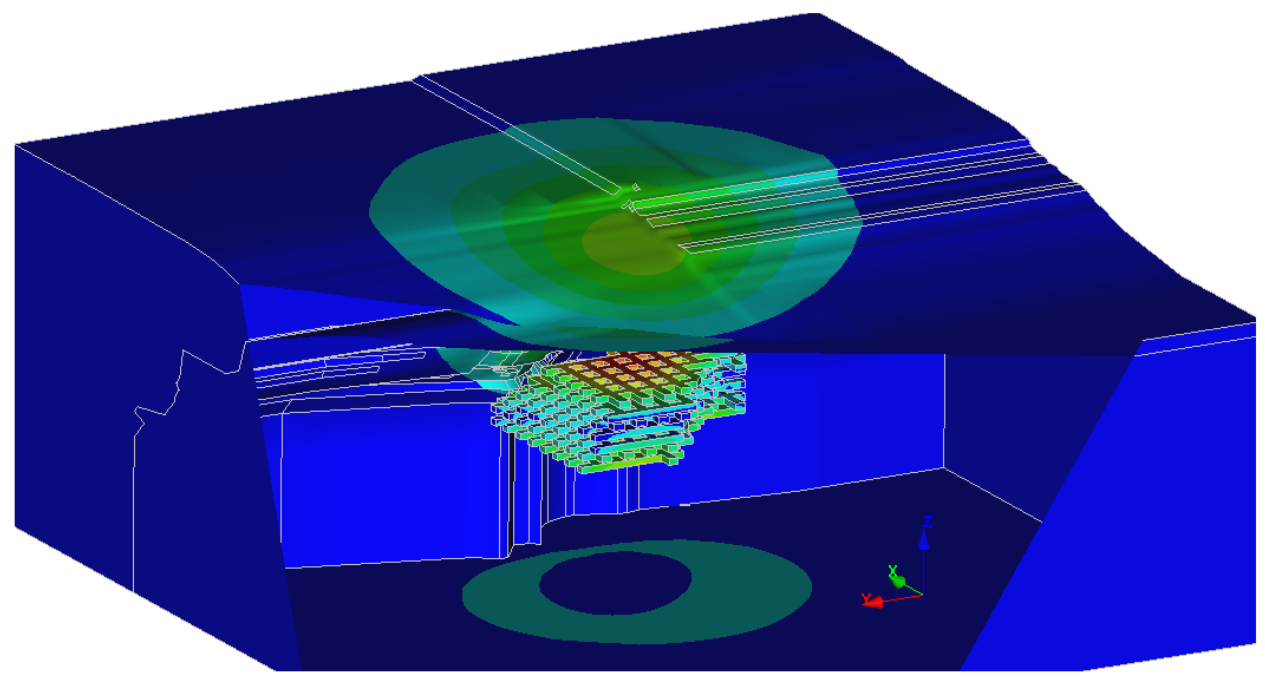

Fig. 3. The norm of the total displacement vector $\mathrm{d}_{\mathrm{uvw}}$ - Cantacuzino mine, from the model with 3D finite elements

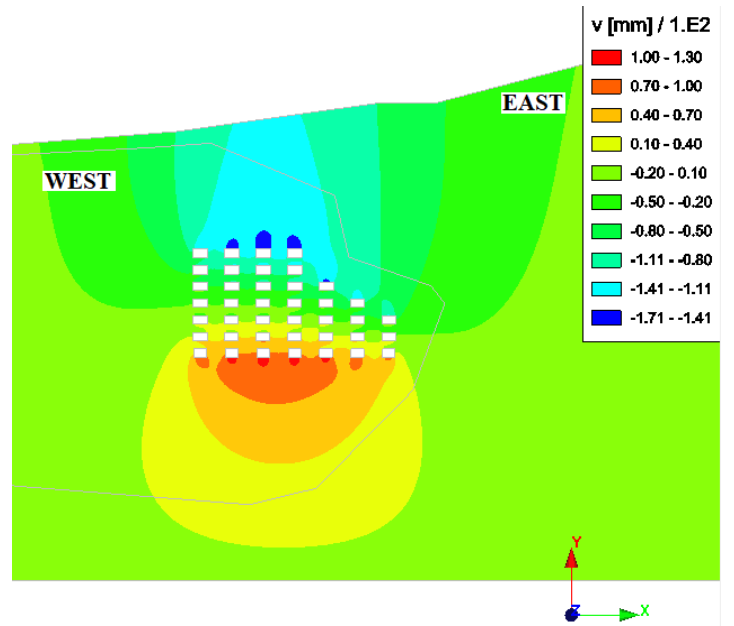

a)

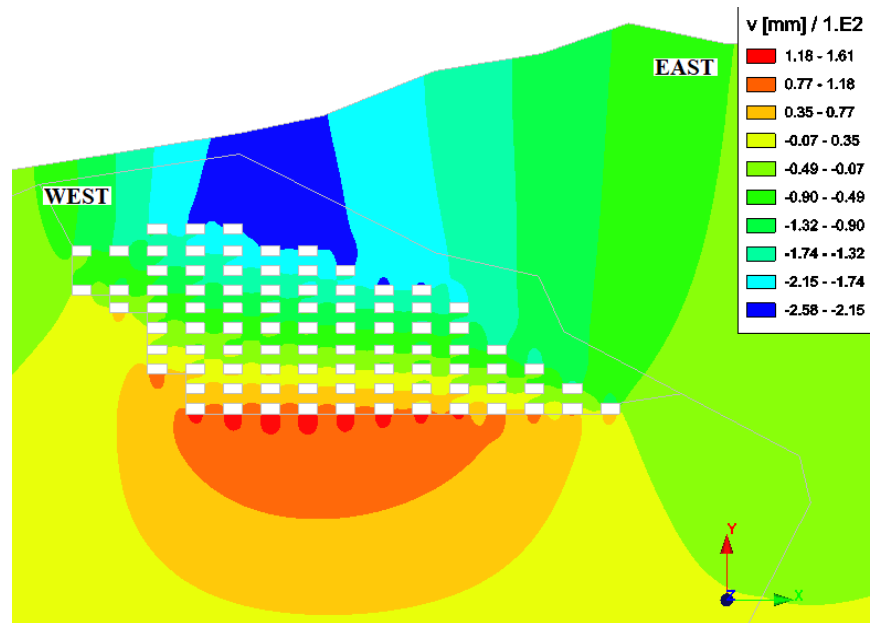

b)

Fig. 4. Vertical displacements $\mathrm{v}$, in $\mathrm{mm}$, from 2D finite element modeling a) Cantacuzino mine b) Victoria mine

The surface subsidence occurred cumulatively, by overlapping the effects generated by the deformation and vertical displacement of the pillars following the successive extraction of the levels. Along with the cumulative vertical displacements of the overlapping pillars, there was an extension of the surface area affected by the underground mining.

As the vertical and horizontal displacements transmitted through the massif have accentuated, in the surface and in the marginal safety ceiling, especially due to the horizontal displacements, cracks occurred that extended in time and due to the effects of seismic waves generated by the explosives detonation. The fractures became ways of infiltration for the water from the surface to the ridge of the rock salt deposit, which produced important dissolutions (as determined by the systematic electrometric measurements performed in the perimeter of Slănic salt mine). Dissolution voids led to the local accentuation of the deformations produced by the mining voids.

We also highlight the fact that the subsidence trough produced at Slănic Prahova salt mine is not a continuous one, with a theoretical geometry like the one represented in figure 1, but is the result of the overlapping effects of the underground mining of the three mining fields Victoria, Unirea and Cantacuzino. Thus, for each point of coordinate $(x, y, z)$, measured at time $t$, we will have the following value of subsidence: 
$W_{(x, y, z, t)}^{\text {total }}=W_{(x, y, z, t)}^{\text {Victoria }}+W_{(x, y, z, t)}^{\text {Unirea }}+W_{(x, y, z, t)}^{\text {Cantacuzin }}$. As a consequence, the total subsidence trough should have at least theoretically three centers of maximum displacement, specific to each mining field. Of course, the existence of other local conditions led to a somewhat random distribution of the surface subsidence (water infiltration on cracks and fissures, local dissolutions on the ridge of the rock salt and around the shafts, landslides associated with subsidence, surface topography, etc.).

\section{Analysis of the surface subsidence measurements in the area of Victoria and Cantacuzino Mines}

In the diagram from figure 5 is presented the organization of information on the analysis of surface deformations of Slănic Prahova salt mine, inspired by a subsidence management scheme for two potassium mines in northeastern Spain, presented in the paper [4]. The specialists from Slănic salt mine practically organized the topographic works, respecting the basic principles presented in this diagram.

The purpose of the topographic measurements on the surface topography was to monitor the vertical displacements of several significant topographic landmarks, placed in the area of influence of Victoria, Unirea and Cantacuzino mines, and to show representative displacements for the analyzed perimeter. For this purpose, a series of fixed points were established, with control coordinates, at which the points with time-varying coordinates were reported, for which the actual monitoring of the surface displacements was performed.

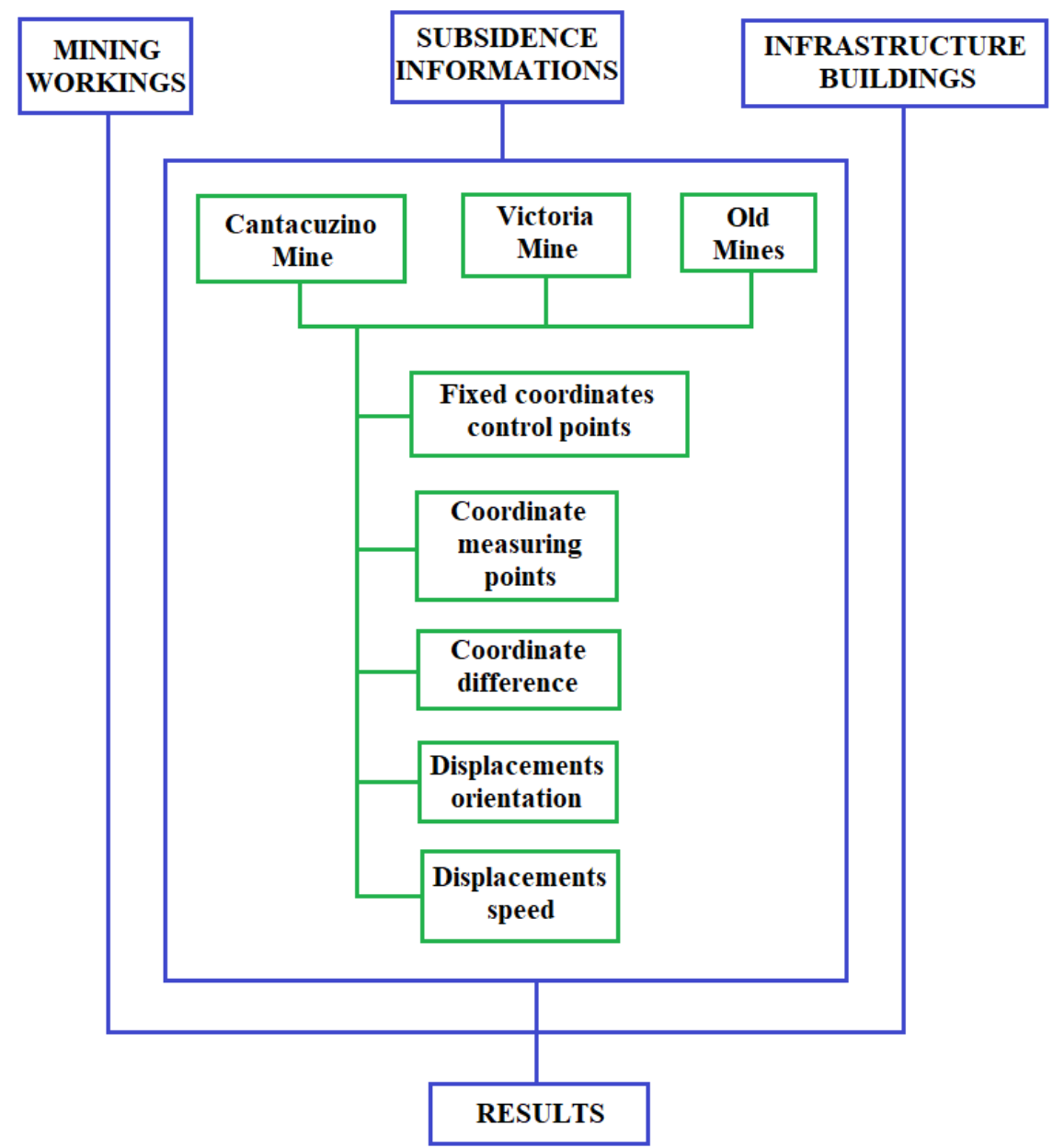

Fig. 5. Surface subsidence analysis diagram at Slănic Prahova salt mine (modified after [4])

At the surface of Slănic salt mine, in the areas of influence of Victoria, Cantacuzino and Unirea mines, topographic landmarks were placed on which measurements of surface subsidence were performed, at intervals of approx. one year, starting in 1994, until now. The situation of the landmarks is as follows: at the Victoria mine, 107 landmarks were placed, on 7 alignments; at Cantacuzino mine, 65 landmarks on 4 alignments; at Unirea mine, 36 landmarks on 5 alignments. These parts were mounted either on the ground or on the foundation of the buildings. The measured vertical displacement values and the subsidence velocity values of each landmark were stored in tabular and graphical form. 


\subsection{Analysis of surface subsidence measurements in the perimeter of Victoria Mine}

In the case of Victoria Mine, the landmarks used to monitor the surface deformation were located on the following alignments: B74-V16N, P1-PA9 (N3), RC38-RC50, V16N-V21N, RC11-RC23 and RC24-RC37. From each alignment were selected the landmarks with the highest subsidence, between $93 \mathrm{~mm}$ (landmark RC 40) and $585 \mathrm{~mm}$ (landmark RC 27), with subsidence speeds of $0.35 \mathrm{~mm} / \mathrm{month}$ and $2.23 \mathrm{~mm} / \mathrm{month}$, respectively. The prognosis functions for subsidence and subsidence speeds, for the selected landmarks, are presented in figures 6 and 7, table no. 1 and table no. 2. For both the prognosis of subsidence and of subsidence speeds, the functions with the best approximation were the linear, logarithmic and power type ones, which highlight a very diverse behavior of the surface deformation phenomena. Based on these functions, the evolution in time of the subsidence and subsidence speeds was predicted over a period of 50 years and is summarized in table no. 3 .

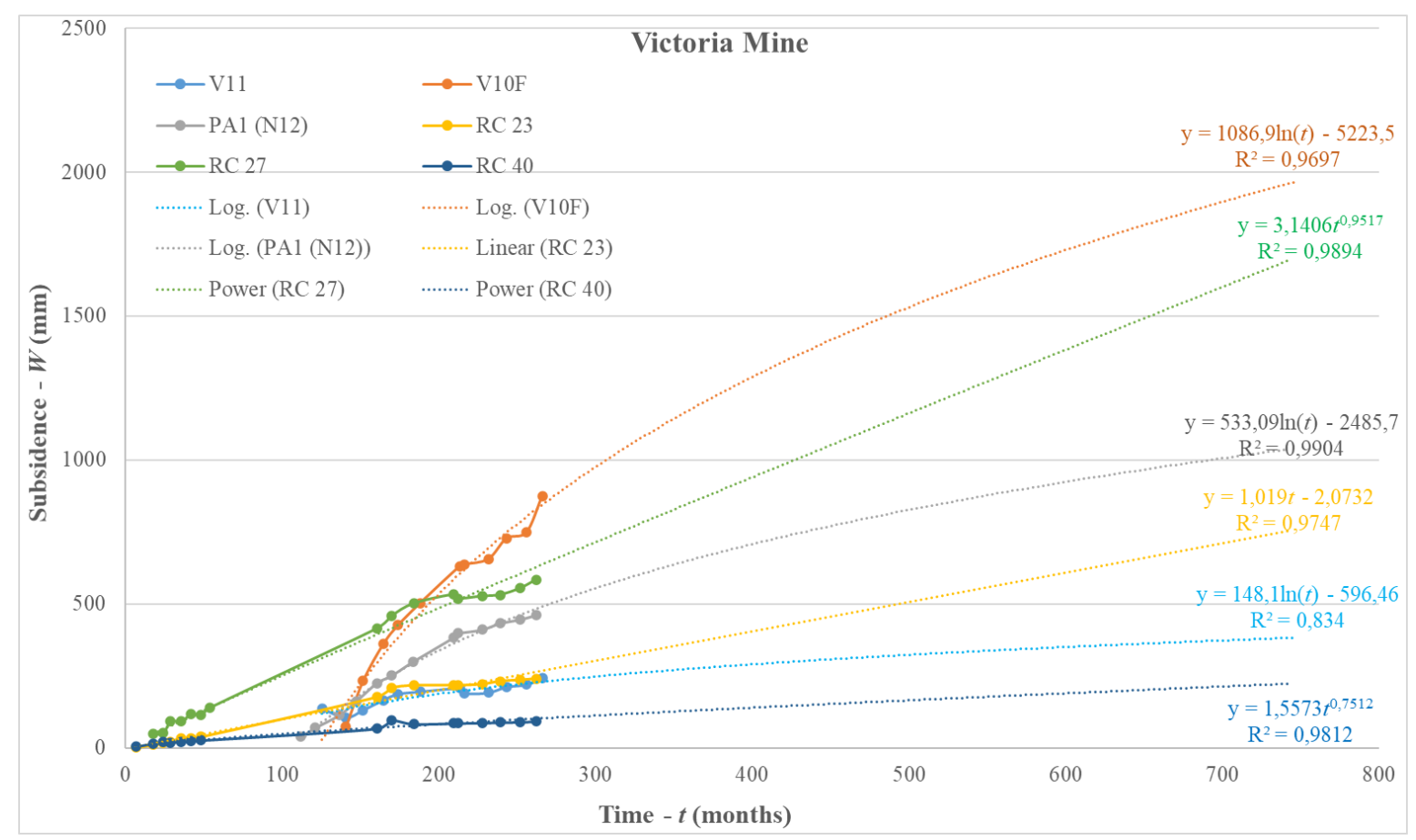

Fig. 6. Subsidence prognosis for the surface landmarks - Victoria Mine [8]

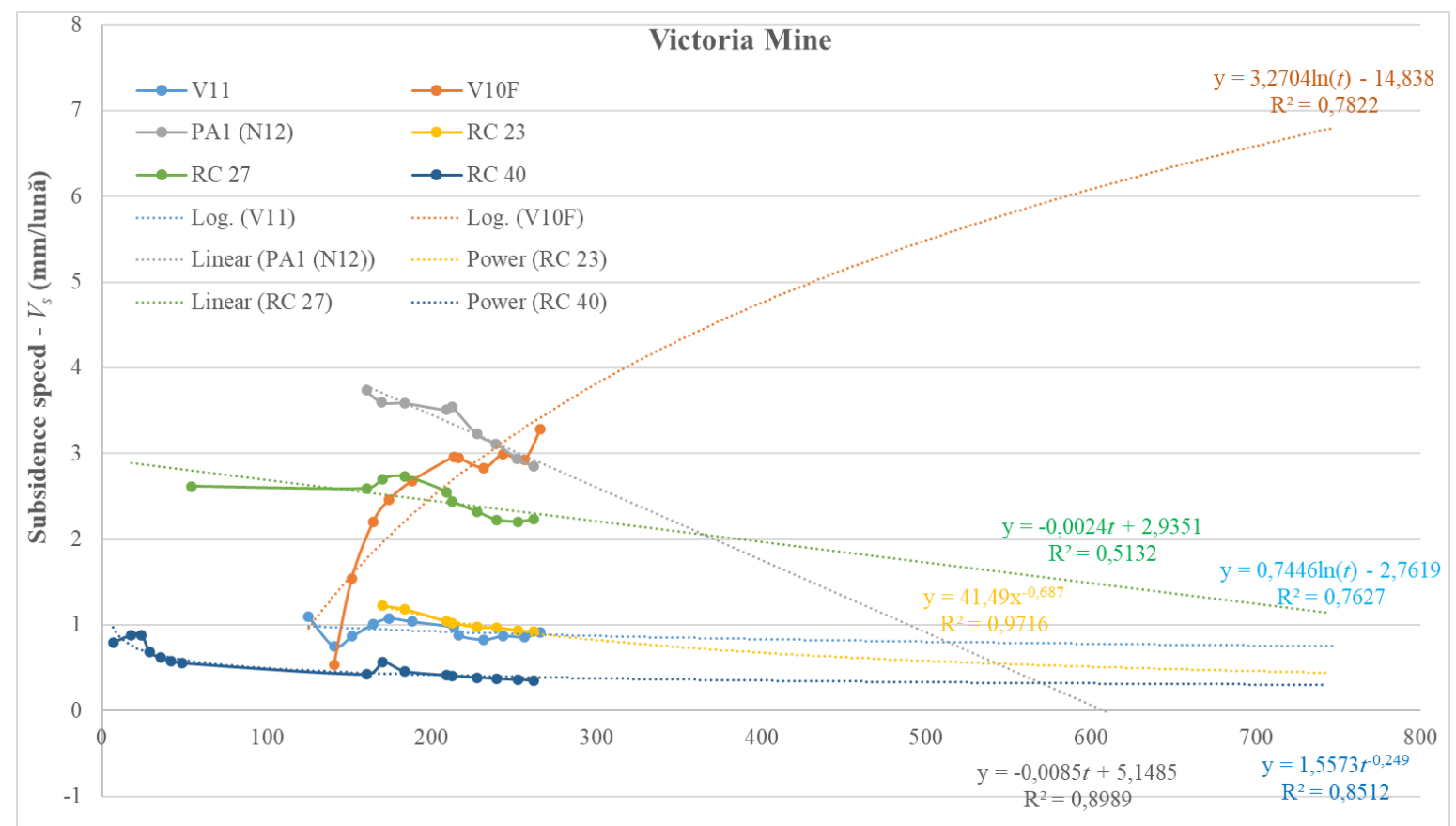

Time - $t$ (months)

Fig. 7. The prognosis of subsidence speeds for the surface landmarks - Victoria Mine [8] 
Table 1. The prognosis functions of the subsidence phenomena for the landmarks with the highest subsidence, from Victoria Mine

\begin{tabular}{|c|l|l|l|l|c|c|}
\hline $\begin{array}{c}\text { Land- } \\
\text { mark }\end{array}$ & Alignment & $\begin{array}{c}\text { Approx. } \\
\text { law }\end{array}$ & $\begin{array}{c}\text { Subsidence approximation } \\
\text { formula, } S_{(t)} \\
\mathbf{m m}\end{array}$ & $\begin{array}{c}\text { Coef., } \\
\mathbf{R}^{\mathbf{2}}\end{array}$ & $\begin{array}{c}\text { Last subsidence } \\
\text { speed, } \\
\mathbf{m m} / \mathbf{m o n t h}\end{array}$ & $\begin{array}{c}\text { Total measured } \\
\text { subsidence, } \\
\text { mm }\end{array}$ \\
\hline V11 & B74-V16N & ogarithmic & $S_{V 11(t)}^{V}=148,7 \cdot \ln (t)-596,46$ & 0.8340 & 0.9115 & 243 \\
\hline $\begin{array}{c}\text { PA1 } \\
\text { (N12) }\end{array}$ & P1-PA9 (N3) & ogarithmic & $S_{P A 1(t)}^{V}=533,09 \cdot \ln (t)-2485,7$ & 0.9904 & 2.8503 & 426 \\
\hline RC40 & Rc38-RC50 power & $S_{R C 40(t)}^{V}=1,5573 \cdot t^{0,7512}$ & 0.9812 & 0.3536 & 93 \\
\hline V10F & V16N-V21N & ogarithmic & $S_{V 10 F(t)}^{V}=1086,9 \cdot \ln (t)-5223,5$ & 0.9697 & 3.289 & 875 \\
\hline RC23 & RC11-RC23 & inear & $S_{R C 23(t)}^{V}=1,019 \cdot t-2,0732$ & 0.9747 & 0.9179 & 241 \\
\hline RC27 & RC24-RC37 power & $S_{R C 27(t)}^{V}=3,1406 \cdot t^{0,9517}$ & 0.9894 & 2.2302 & 585 \\
\hline
\end{tabular}

Table 2. Approximation of the subsidence speed of the surface landmarks with maximum subsidence, from the Victoria Mine

\begin{tabular}{|c|c|l|l|c|c|c|}
\hline $\begin{array}{c}\text { Land- } \\
\text { mark }\end{array}$ & Alignment & $\begin{array}{c}\text { Approx. } \\
\text { law }\end{array}$ & $\begin{array}{c}\text { Approximation formula of the } \\
\text { subsidence speed } \\
\boldsymbol{V}_{\boldsymbol{S}(t)}, \mathbf{m m} / \mathbf{m o n t h}\end{array}$ & $\begin{array}{c}\text { Last } \\
\text { Coef., } \\
\mathbf{R}^{\mathbf{2}}\end{array}$ & $\begin{array}{c}\text { subsidence } \\
\text { speed, } \\
\mathbf{m m} \mathbf{m o n t h}\end{array}$ & $\begin{array}{c}\text { Total } \\
\text { subsidence, } \\
\text { mm }\end{array}$ \\
\hline V11 & B74-V16N & ogarithmic & $V_{V 11(t)}^{V}=0.7446 \cdot \ln (t)-2.7619$ & 0,8340 & 0,9115 & 243 \\
\hline $\begin{array}{c}\text { PA1 } \\
\text { (N12) }\end{array}$ & P1-PA9 (N3) & ogarithmic & $V_{P A 1(t)}^{V} 533.09 \cdot \ln (t)-2485.7$ & 0,9904 & 2,8503 & 426 \\
\hline RC40 & RC38-RC50 power & $V_{R C 27(t)}^{V}=3.1406 \cdot t^{0,9517}$ & 0,9894 & 0,3536 & 93 \\
\hline V10F & V16N-V21N & ogarithmic & $V_{V 10 F(t)}^{V}=1086.9 \cdot \ln (t)-5223.5$ & 0,9697 & 3,289 & 875 \\
\hline RC23 & RC11-RC23 & inear & $V_{R C 23(t)}^{V}=1.019 \cdot t-2.0732$ & 0,9747 & 0,9179 & 241 \\
\hline RC27 & RC24-RC37 & power & $V_{R C 40}^{V}=1.5573 \cdot t^{0,7512}$ & 0,9812 & 2,2302 & 585 \\
\hline
\end{tabular}

Table 3. The values of the subsidence and subsidence speeds predicted in time for the landmarks with the highest subsidence value on the alignment, from Mina Victoria - [8]

\begin{tabular}{|c|c|c|c|c|c|c|c|c|c|c|c|}
\hline \multirow{3}{*}{$\begin{array}{l}\text { Land- } \\
\text { mark }\end{array}$} & \multirow{3}{*}{ Parameter } & \multicolumn{10}{|c|}{ Time } \\
\hline & & $\begin{array}{c}5 \\
\text { years }\end{array}$ & $\begin{array}{c}10 \\
\text { years }\end{array}$ & $\begin{array}{c}15 \\
\text { years }\end{array}$ & $\begin{array}{c}20 \\
\text { years }\end{array}$ & $\begin{array}{c}25 \\
\text { years }\end{array}$ & $\begin{array}{c}30 \\
\text { years }\end{array}$ & $\begin{array}{c}35 \\
\text { years }\end{array}$ & $\begin{array}{c}40 \\
\text { years }\end{array}$ & $\begin{array}{c}45 \\
\text { years }\end{array}$ & $\begin{array}{c}50 \\
\text { years }\end{array}$ \\
\hline & & $\begin{array}{c}60 \\
\text { months }\end{array}$ & $\begin{array}{c}120 \\
\text { months }\end{array}$ & $\begin{array}{c}180 \\
\text { months }\end{array}$ & $\begin{array}{c}240 \\
\text { months }\end{array}$ & $\begin{array}{c}300 \\
\text { months }\end{array}$ & \begin{tabular}{|c|}
360 \\
months \\
\end{tabular} & $\begin{array}{c}420 \\
\text { months }\end{array}$ & $\begin{array}{c}480 \\
\text { months }\end{array}$ & $\begin{array}{c}540 \\
\text { months }\end{array}$ & $\begin{array}{c}600 \\
\text { months }\end{array}$ \\
\hline \multirow[b]{2}{*}{ V11 } & $S_{(t)}, \mathbf{m m}$ & 261 & 286 & 307 & 326 & 342 & 357 & 371 & 383 & 395 & 405 \\
\hline & $\begin{array}{c}V_{S(t)}, \\
\text { mm/month }\end{array}$ & 1.5474 & 1.6731 & 1.7807 & 1.8746 & 1.9580 & 2.0330 & 21012 & 2.1636 & 2.2212 & 2.2746 \\
\hline \multirow{2}{*}{$\begin{array}{l}\text { PA1 } \\
\text { (N12) }\end{array}$} & $S_{(t)}, \mathbf{m m}$ & 593 & 684 & 762 & 829 & 890 & 944 & 993 & 1038 & 1079 & 1118 \\
\hline & $\begin{array}{c}V_{S(t)} \\
\text { mm/month }\end{array}$ & 2.4112 & 1.9012 & 1.3912 & 0.8812 & 0.3712 & -0.1388 & -0.6488 & -1.1588 & -1.6688 & -2.1788 \\
\hline \multirow[b]{2}{*}{ RC40 } & $S_{(t)}, \mathbf{m m}$ & 119 & 136 & 151 & 166 & 181 & 195 & 209 & 223 & 237 & 250 \\
\hline & $\begin{array}{c}V_{S(t)} \\
\text { mm/month }\end{array}$ & 6.5590 & 6.8441 & 7.0973 & 7.3258 & 7.5346 & 7.7274 & 7.9066 & 8.0744 & 8.2322 & 8.3814 \\
\hline \multirow{2}{*}{ V10F } & $S_{(t)}, \mathbf{m m}$ & 1067 & 1250 & 1407 & 1544 & 1666 & 1776 & 1875 & 1966 & 2050 & 2128 \\
\hline & $\begin{array}{r}V_{S} \\
\mathbf{m m} / \mathbf{m}\end{array}$ & 4.0891 & 4.6414 & 5.1137 & 5.5263 & 5.8927 & 6.2221 & 6.5214 & 6.7955 & 7.0485 & 7.2832 \\
\hline \multirow[b]{2}{*}{ RC23 } & $S_{(t)}, \mathbf{m m}$ & 326 & 387 & 448 & 509 & 571 & 632 & 693 & 754 & 815 & 876 \\
\hline & $\begin{array}{c}V_{S(t)} \\
\text { mm/month } \\
\end{array}$ & 0.7853 & 0.6983 & 0.6317 & 0.5788 & 0.5356 & 0.4996 & 0.4689 & 0.4426 & 0.4195 & 0.3992 \\
\hline \multirow[b]{2}{*}{ RC27 } & $S_{(t)}, \mathbf{m m}$ & 765 & 900 & 1034 & 1168 & 1300 & 1432 & 1563 & 1694 & 1824 & 1953 \\
\hline & $\begin{array}{c}V_{S(t)} \\
\mathrm{mm} / \mathrm{month}\end{array}$ & 2.1622 & 2.0182 & 1.8742 & 1.7302 & 1.5862 & 1.4422 & 1.2982 & 1.1542 & 1.0102 & 0.8662 \\
\hline
\end{tabular}


vol. 27 , issue $2 / 2021$

pp. $14-29$

For the values of subsidence and subsidence speeds in the area of Victoria mine, after the measurements performed on 11.06.2019, the scalar maps from figures 8 and 9 were elaborated by interpolation.
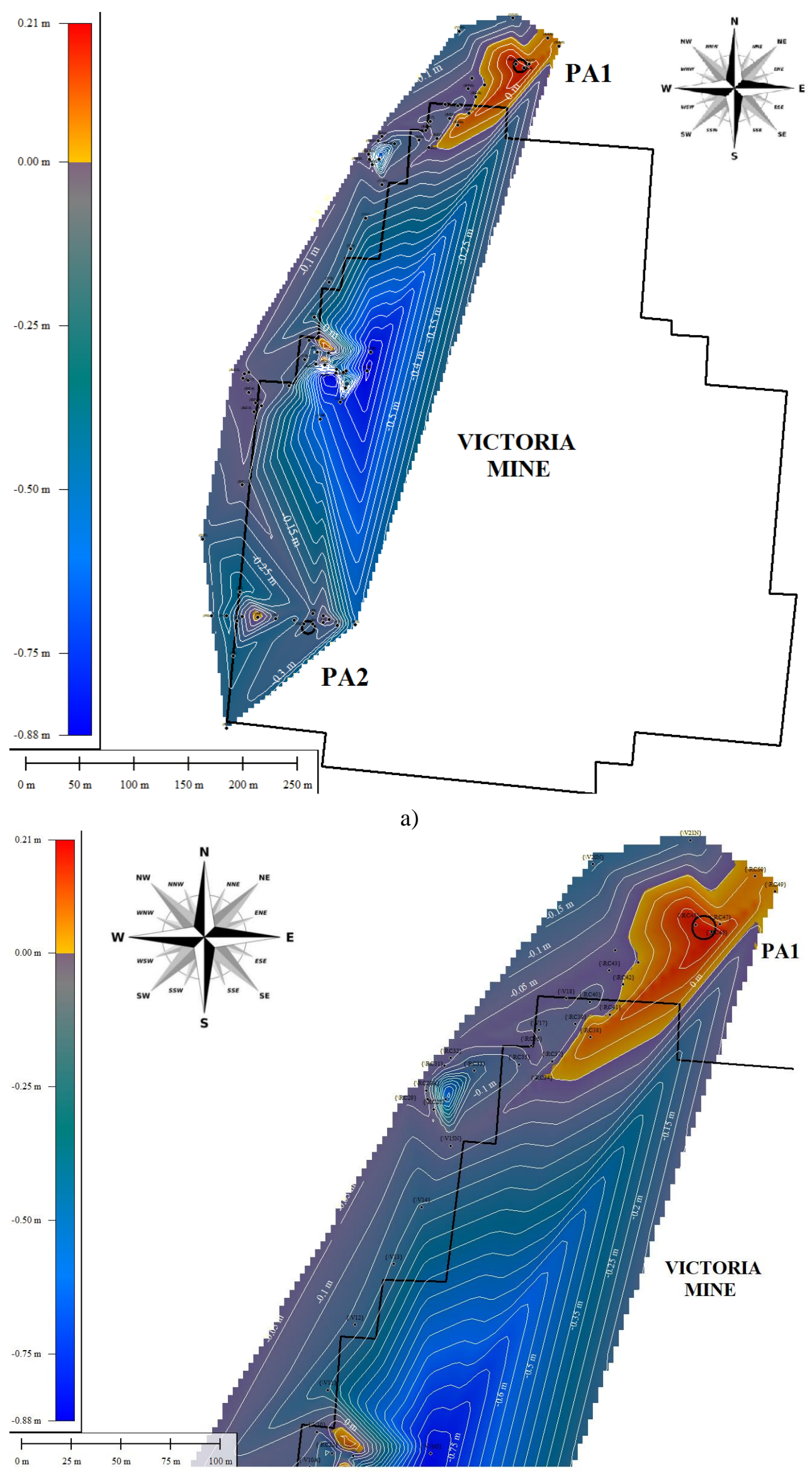

b) 


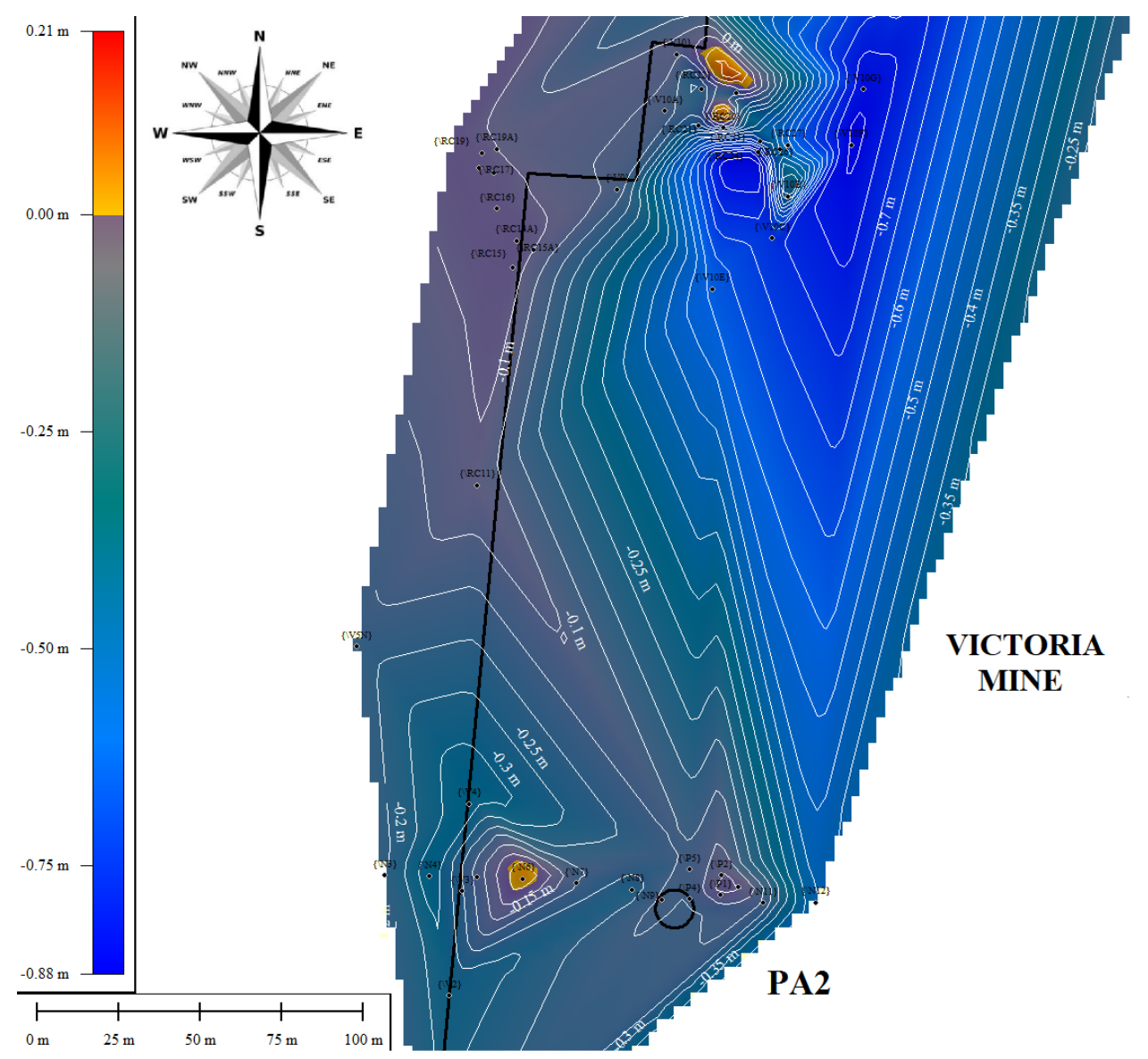

c)

Fig. 8. Scalar representation of subsidence, measured at the surface until 11.06.2019, in the area of influence of Victoria Mine [8]; a) Overview; b) Detail of the Northern area; c) Detail of the Southern area

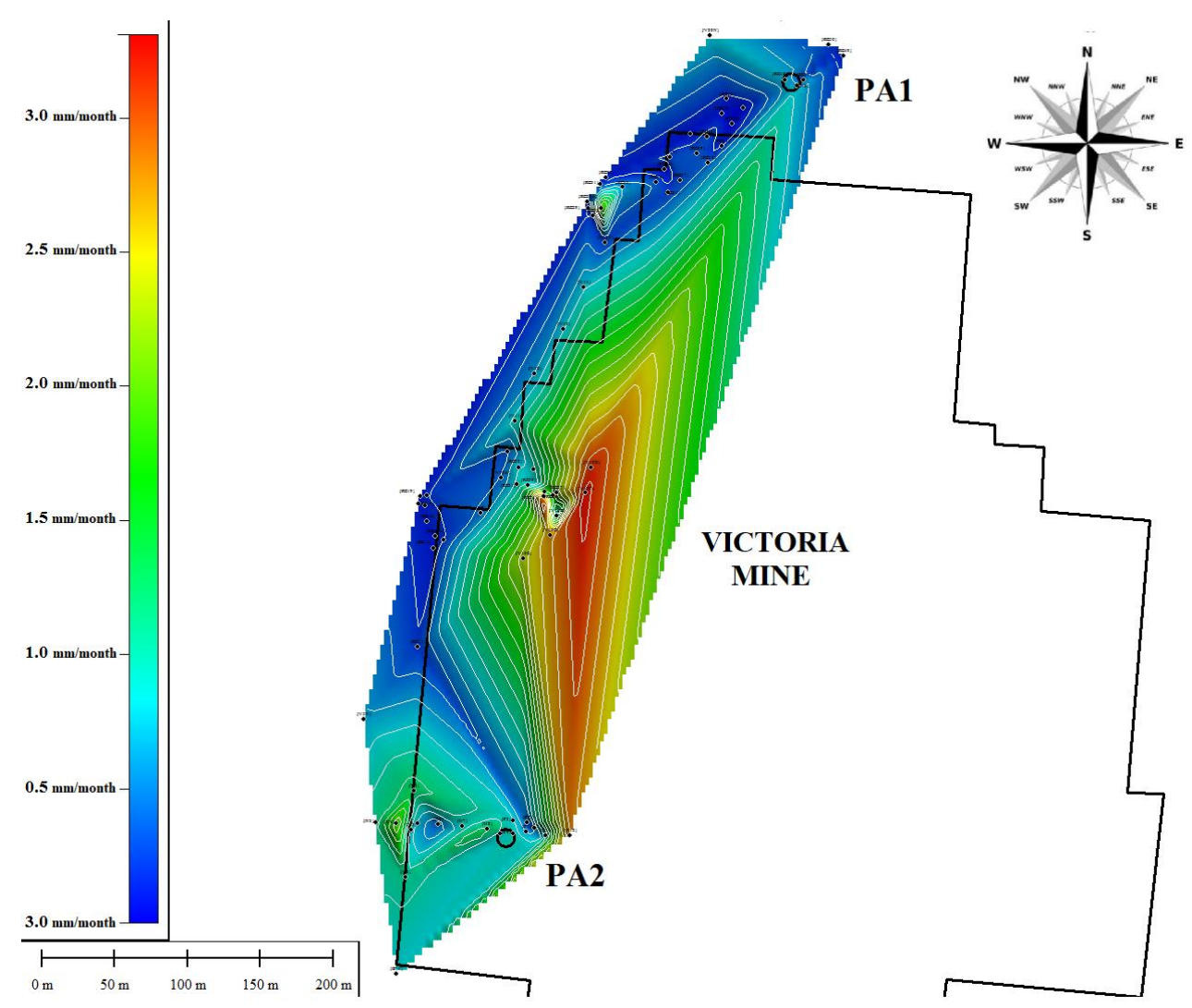

Fig. 9. Scalar representation of the subsidence speeds, determined on 11.06.2019, in the area of influence of Victoria Mine [8] 
In order to analyze the evolution in time of subsidence at Victoria Mine, from each alignment in the area of influence of this mine, the landmarks with the highest cumulative subsidence were selected, for which a prognosis equation was determined. For most landmarks, the approximation equations are logarithmic and power type, determined with a very good degree of accuracy (coefficients of determination being $\mathrm{R}^{2}=0.83-0.99$ ). These prognosis formulas show that the deformation of the surface attenuates over time (figure 6), a phenomenon also explained by the decreasing tendencies of the subsidence speeds, presented in figure 7.

With the help of the approximation equations synthesized in table no. 1, the subsidence values at the level of the selected landmarks have been predicted for a period of 50 years (table no. 4). Analyzing the evolution graphs of subsidence, it can be seen that the deformation trends of the surface are similar for landmarks located in the vicinity of those analyzed.

Table 4. The values of predicted subsidence in time for the landmarks with the highest subsidence, from Victoria Mine - [8]

\begin{tabular}{|c|c|c|c|c|c|c|c|c|c|c|}
\hline \multirow{3}{*}{ Landmark } & \multicolumn{10}{|c|}{ Predicted subsidence $S_{(t)}, \mathbf{m m}$} \\
\hline & $\begin{array}{c}5 \\
\text { years }\end{array}$ & $\begin{array}{c}10 \\
\text { years }\end{array}$ & $\begin{array}{c}15 \\
\text { years }\end{array}$ & $\begin{array}{c}20 \\
\text { years }\end{array}$ & \begin{tabular}{|c|}
25 \\
years
\end{tabular} & $\begin{array}{c}30 \\
\text { years }\end{array}$ & $\begin{array}{c}35 \\
\text { years }\end{array}$ & $\begin{array}{c}40 \\
\text { years }\end{array}$ & $\begin{array}{c}45 \\
\text { years }\end{array}$ & $\begin{array}{c}50 \\
\text { years }\end{array}$ \\
\hline & $\begin{array}{c}60 \\
\text { months }\end{array}$ & $\begin{array}{c}120 \\
\text { months }\end{array}$ & $\begin{array}{c}180 \\
\text { months }\end{array}$ & $\begin{array}{c}240 \\
\text { months }\end{array}$ & $\begin{array}{c}300 \\
\text { months }\end{array}$ & $\begin{array}{c}360 \\
\text { months }\end{array}$ & $\begin{array}{c}420 \\
\text { months }\end{array}$ & $\begin{array}{c}480 \\
\text { months }\end{array}$ & $\begin{array}{c}540 \\
\text { months }\end{array}$ & $\begin{array}{c}600 \\
\text { months }\end{array}$ \\
\hline & 261 & 286 & 307 & 326 & 342 & 357 & 371 & 383 & 395 & 405 \\
\hline PA1 & 59 & \begin{tabular}{|l|}
684 \\
\end{tabular} & 762 & 829 & 890 & 944 & 993 & 1038 & 1079 & 1118 \\
\hline RC40 & 119 & 136 & 151 & 166 & 181 & 195 & 209 & 223 & 237 & 25 \\
\hline V10 & 1067 & 1250 & 1407 & 1544 & 1666 & 1776 & 1875 & 1966 & 2050 & 2128 \\
\hline RC23 & 326 & 387 & 448 & 509 & 571 & 632 & 693 & 754 & 815 & 876 \\
\hline RC27 & 765 & 900 & 1034 & 1168 & 1300 & 1432 & 1563 & 1694 & 1824 & 1953 \\
\hline
\end{tabular}

\subsection{Analysis of surface subsidence measurements in the perimeter of Cantacuzino Mine}

The landmarks used to monitor the deformation of the surface under the influence of Cantacuzino Mine were located on the following alignments: C1-RC11, RC9-RC26, S1-S15, C1-C16D and C1-C16D. From each alignment were selected the landmarks with the highest subsidence, between $113.6 \mathrm{~mm}$ (landmark RC2) and $295.9 \mathrm{~mm}$ (landmark C16D), with subsidence speeds of $0.38 \mathrm{~mm} / \mathrm{month}$, respectively $0.81 \mathrm{~mm} / \mathrm{month}$. The prognosis functions for subsidence and subsidence speeds, for the selected landmarks, are presented in table no. 5 and no. 6. For both the prognosis of subsidence and subsidence speeds, the functions with the best approximation were the linear ones, due to the fact that only the last two measurements were available. The evolution in time of subsidence and subsidence speeds, over a period of 20 years, is summarized in table no. 7. Although the observations made on the analyzed landmarks were made over a longer period of time, only the last two measurement campaigns were accessed. Therefore, the credibility of the linear approximation laws presented in this paper, for the surface from Cantacuzino mine, is acceptable only for a maximum of 15-20 years.

For the values of subsidence and subsidence speeds in the area of Cantacuzino mine, after the measurements performed on 11.06.2019, the scalar maps in figures 10 and 11 were elaborated by interpolation.

Table 5. The prognosis functions of the subsidence phenomena for the landmarks with the highest subsidence, from Cantacuzino Mine

\begin{tabular}{|c|c|l|l|l|c|c|}
\hline $\begin{array}{c}\text { Land- } \\
\text { mark }\end{array}$ & Alignment & $\begin{array}{c}\text { Approx. } \\
\text { law }\end{array}$ & $\begin{array}{c}\text { Subsidence approximation } \\
\text { formula, } \boldsymbol{S}_{(t)} \\
\mathbf{m m}\end{array}$ & $\begin{array}{c}\text { Coef., } \\
\mathbf{R}^{2}\end{array}$ & $\begin{array}{c}\text { Last } \\
\text { subsidence } \\
\text { speed, } \\
\text { mm/month }\end{array}$ & $\begin{array}{c}\text { Total } \\
\text { measured } \\
\text { subsidence, } \\
\text { mm }\end{array}$ \\
\hline RC2 & C1-RC11 & linear & $S_{R C 2(t)}^{C}=0.4734 \cdot t-27.964$ & 1.00 & 0.3799 & 113.6 \\
\hline RC24 & RC9-RC26 & linear & $S_{R C 24(t)}^{C}=1.1107 \cdot t-113.63$ & 1.00 & 0.7307 & 219.0 \\
\hline S15 & S1-S15 & linear & $S_{S 15(t)}^{C}=1.0743 \cdot t-152.24$ & 1.00 & 0.5652 & 169.0 \\
\hline C15 & C1-C16D & linear & $S_{C 15(t)}^{C}=0.9833 \cdot t-6.0179$ & 1.00 & 0.9632 & 288 \\
\hline C16D & C1-C16D & linear & $S_{C 16 D(t)}^{C}=1.6115 \cdot t-185.96$ & 1.00 & 0.808 & 295.9 \\
\hline
\end{tabular}


Table 6. Approximation of the subsidence speed of the landmarks from the surface with the maximum subsidence, from Cantacuzino Mine

\begin{tabular}{|c|c|l|l|c|c|c|}
\hline $\begin{array}{c}\text { Land- } \\
\text { mark }\end{array}$ & Alignment & $\begin{array}{c}\text { Approx. } \\
\text { law }\end{array}$ & $\begin{array}{c}\text { Approximation formula of the } \\
\text { subsidence speed } \\
\boldsymbol{V}_{S(t)}, \mathbf{m m} / \mathbf{m o n t h}\end{array}$ & $\begin{array}{c}\text { Last } \\
\text { Coef., } \\
\mathbf{R}^{2}\end{array}$ & $\begin{array}{c}\text { Lubsidence } \\
\text { speed, } \\
\text { mm/month }\end{array}$ & $\begin{array}{c}\text { Total } \\
\text { subsidence, } \\
\text { mm }\end{array}$ \\
\hline RC2 & C1-RC11 & linear & $V_{R C 2(t)}^{C}=0.0003 \cdot t+0.2828$ & 1.00 & 0.3799 & 113.6 \\
\hline RC24 & RC9-RC26 & linear & $V_{R C 24(t)}^{C}=0.0013 \cdot t+0.3362$ & 1.00 & 0.7307 & 219.0 \\
\hline S15 & S1-S15 & linear & $V_{S 15(t)}^{C}=0.0018 \cdot t+0.0366$ & 1.00 & 0.5652 & 169.0 \\
\hline C15 & C1-C16D & linear & $V_{C 15(t)}^{C}=7 \cdot 10^{-5} \cdot t+0.9423$ & 1.00 & 0.9632 & 288 \\
\hline C16D & C1-C16D & linear & $V_{C 16 D(t)}^{C}=0.0022 \cdot t+0.3439$ & 1.00 & 0.808 & 295.9 \\
\hline
\end{tabular}

Table 7. The values of subsidence and subsidence speeds predicted in time for the landmarks with the highest subsidence on the alignment, from Cantacuzino Mine

\begin{tabular}{|c|c|c|c|c|c|}
\hline \multirow{3}{*}{ Landmark } & \multirow{3}{*}{ Parameter } & \multicolumn{4}{|c|}{ Time } \\
\hline & & 5 years & 10 years & 15 years & 20 years \\
\hline & & 60 months & 120 months & 180 months & 240 months \\
\hline \multirow{2}{*}{ RC2 } & $S_{(t)}, \mathbf{m m}$ & 142 & 170 & 199 & 227 \\
\hline & 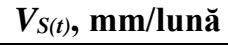 & 0.39050 & 0.40850 & 0.42650 & 0.44450 \\
\hline \multirow{2}{*}{ RC24 } & $S_{(t)}, \mathbf{m m}$ & 272 & 337 & 401 & 465 \\
\hline & $V_{S(t)}, \mathbf{m m} / \mathbf{l u n a ̆}$ & 0.80292 & 0.88092 & 0.95892 & 1.03692 \\
\hline \multirow{2}{*}{ S15 } & $S_{(t)}, \mathbf{m m}$ & 233 & 298 & 362 & 427 \\
\hline & $V_{S(t)}, \mathbf{m m} / \mathbf{l u n a ̆}$ & 0.68283 & 0.79083 & 0.89883 & 1.00683 \\
\hline \multirow{2}{*}{ C15 } & $S_{(t)}, \mathbf{m m}$ & 347 & 406 & 465 & 524 \\
\hline & $V_{S(t)}, \mathbf{m m} / \mathbf{l u n a ̆}$ & 0.96743 & 0.97163 & 0.97583 & 0.98003 \\
\hline \multirow{2}{*}{ C16D } & $S_{(t)}, \mathbf{m m}$ & 393 & 489 & 586 & 683 \\
\hline & $V_{S(t)}, \mathbf{m m} /$ lună & 1.13374 & 1.26574 & 1.39774 & 1.52974 \\
\hline
\end{tabular}

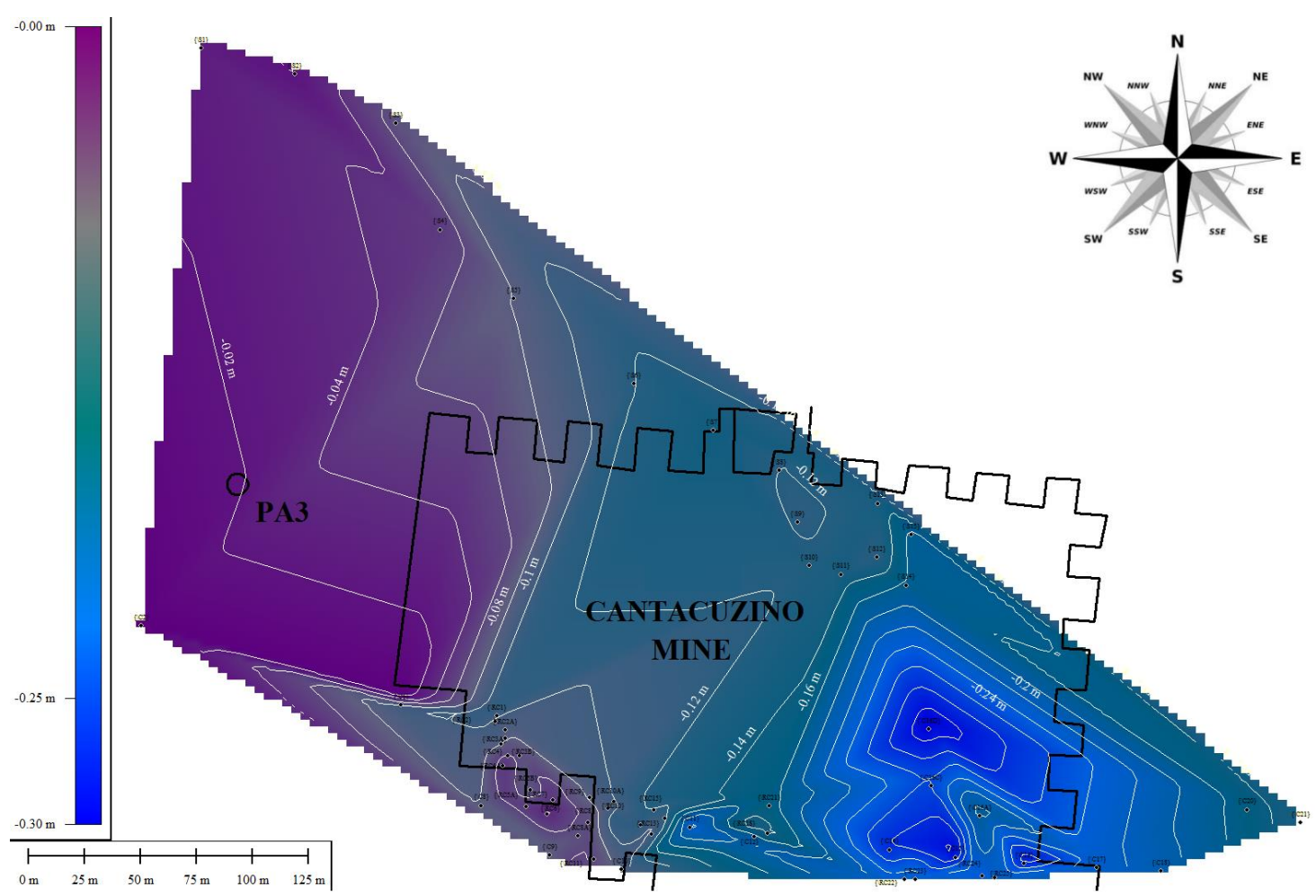

Fig. 10. Scalar representation of the subsidence, measured at the surface until 20.06.2019, in the area of influence of Cantacuzino Mine [8] 
pp. 14-29

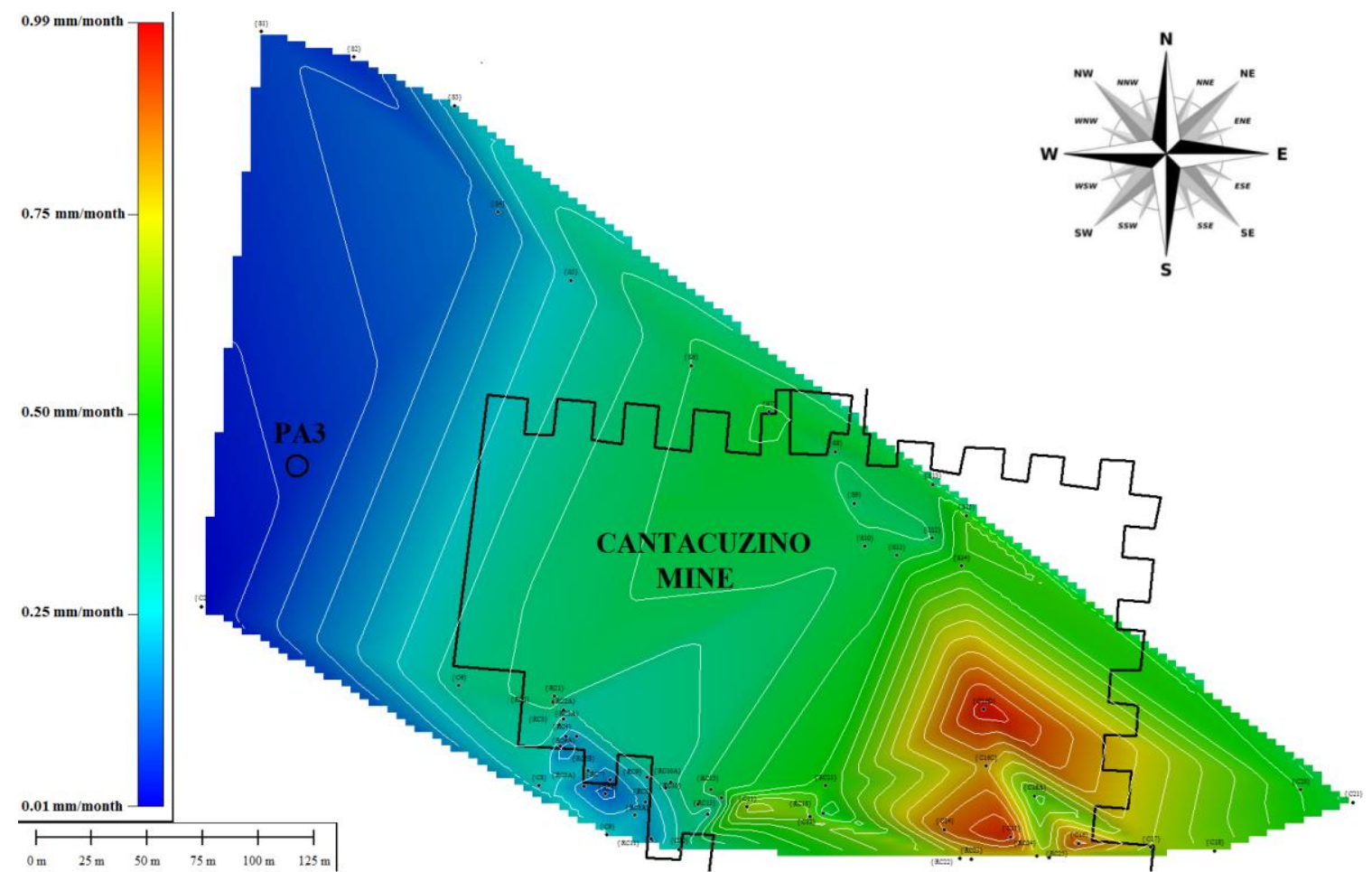

Fig. 11. Scalar representation of the subsidence speeds, determined on 20.06.2019, in the area of influence of Cantacuzino Mine [8]

In the case of the monitoring area placed under the influence of Cantacuzino mine, it was not possible to make a good estimation of the evolution of the subsidence and subsidence speeds over time, due to the fact that only the last two measurement campaigns were accessed. Therefore, the estimation made only for the last two values could only lead to some linear prognosis functions (table no. 7), acceptable only for a maximum period of 15-20 years (table no. 8).

Table 8. The values of subsidence predicted in time for the landmarks with the highest subsidence, from Cantacuzino Mine

\begin{tabular}{|c|r|r|r|r|}
\hline \multirow{2}{*}{ Landmark } & \multicolumn{4}{|c|}{ Predicted subsidence $\boldsymbol{S}_{(t)}, \mathbf{m m}$} \\
\cline { 2 - 5 } & \multicolumn{1}{|c|}{ 5 years } & \multicolumn{1}{|c|}{ 10 years } & 15 years & 20 years \\
\cline { 2 - 5 } & $\mathbf{6 0}$ months & $\mathbf{1 2 0}$ months & 180 months & $\mathbf{2 4 0}$ months \\
\hline RC2 & 142 & 170 & 199 & 227 \\
\hline RC24 & 272 & 337 & 401 & 465 \\
\hline S15 & 233 & 298 & 362 & 427 \\
\hline C15 & 347 & 406 & 465 & 524 \\
\hline C16D & 393 & 489 & 586 & 683 \\
\hline
\end{tabular}

\section{Factors that contributed to the occurrence of subsidence phenomena on the surface of Victoria and Cantacuzino Mines}

\section{The dimensions of the voids resulting from underground mining}

The spatial dimensions (height, width and length) for Victoria and Cantacuzino mines, their relative arrangement to each other and the shape of the voids in the rock salt massif had a decisive influence on the distribution and amplitude of the deformation values transmitted to the surface (in relation to the depth of the voids related to the surface).

The high amplitude of displacements generated by the important dimensions of the mining excavations is evident in the case of underground mining with small rooms and square pillars, the total volume of mining excavations (for the Victoria mine, is approx. $2362324 \mathrm{~m}^{3}$ ) had the greatest influence on the transmission of movements through the massif, to the surface and even to the collapse of the underground structures that took place at the Victoria mine. 


\section{Depth of the deposit}

The depths of the excavations at Slănic Prahova salt mine are between $49 \mathrm{~m}$ and $380 \mathrm{~m}$ (for Victoria Mine) and between $111 \mathrm{~m}$ and $282 \mathrm{~m}$ (for Cantacuzino Mine).

Depending on the rheological behavior of the rock salt from Slănic [9], 3 creep zones were identified, for which the states of long-term stability, relative stability and instability of the rock salt were defined.

Zone I: for the depth $H<267 \mathrm{~m}$, elastic behavior of the rock salt massif - unlimited stability (figure 12.a);

Zone II: for the depth $\mathrm{H}=267$ - $476 \mathrm{~m}$, elastic-plastic behavior of the rock salt massif - of relative stability (figure 12.b);

Zone III, for the depth $H>476 \mathrm{~m}$, plastic and visco-plastic behavior of the rock salt massif - of instability (figure 12.c).

A simple analysis of Figures 12.a and 12.b shows that the only stages reached by a relative stability generated by the creep behavior of the rock salt, as a function of depth, are levels X, XI and XII, from the Victoria mine and all levels of future Slănic Mine (except the $+145 \mathrm{~m}$ level, from the southern boundary of the deposit, below Cantacuzino mine).

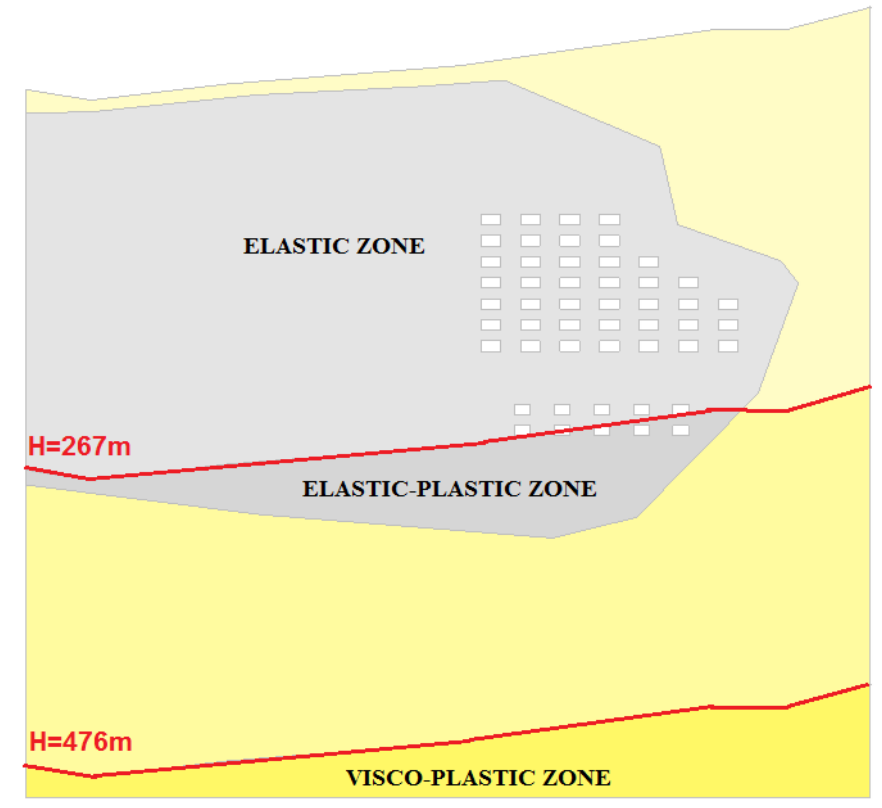

a)

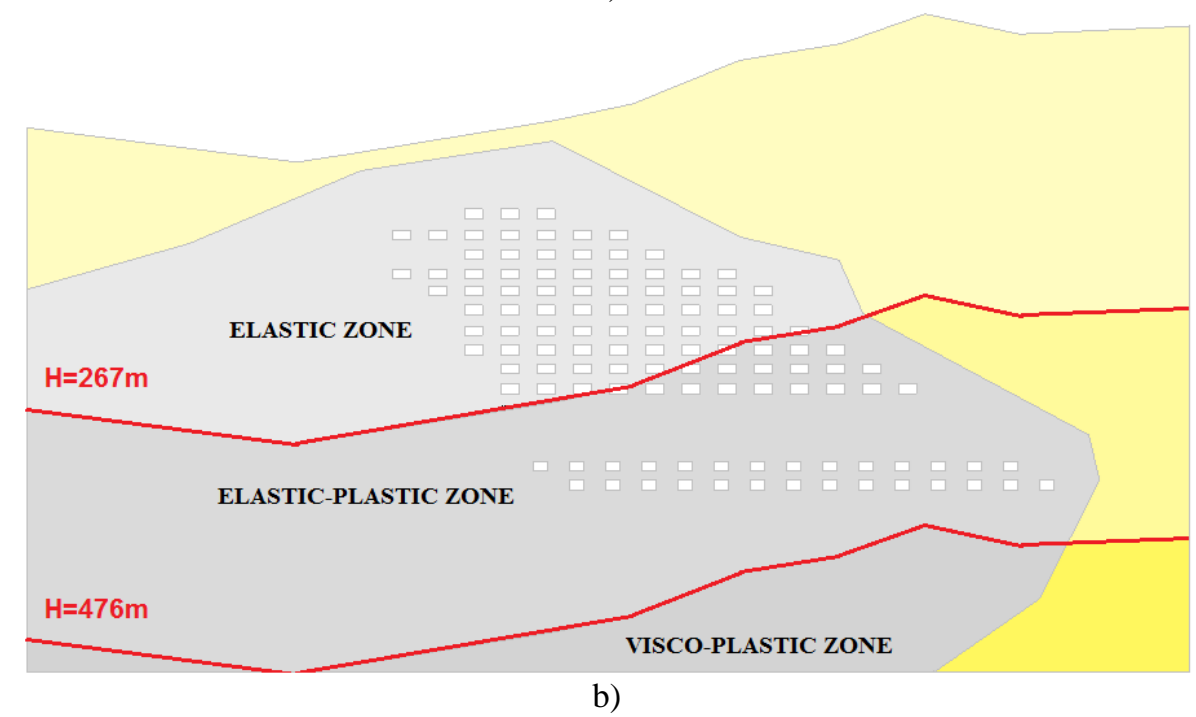

Fig. 12. Depth representation of the areas with elastic, elastic-plastic and visco-plastic behavior, in representative cross sections through: a) Cantacuzino Mine-New Mine Slănic; b) Mina Victoria- New Mine Slănic

The natural state of stress is directly influenced by depth [10]. The horizontal natural stresses calculated according to the Poisson's ratio have the value of approx. 39-40\% of the vertical geostatic stresses. However, the analysis of the instability phenomena from Slănic Prahova salt mine proves that the horizontal stresses, 
even in the conditions of the lack of in situ measurements, can be estimated as being at least equal to the vertical ones. In conclusion, among other causes, the high value of horizontal stresses can be considered a main factor that contributed to the amplification of instability phenomena at Slănic Prahova salt mine.

\section{Geomechanical characteristics of the rock salt deposit and surrounding rocks}

Regarding the dependencies between the deformation of the land and the physical-mechanical, elastic and rheological characteristics, the most important are those geomechanical characteristics that determine the reduction/convergence of the volume of underground mining excavations. First of all, we mention the elastic characteristics of the rock salt, for the elastic area, namely the modulus of elasticity and the Poisson's ratio, then the creep deformation characteristics and the rheological characteristics, for the elastic-plastic area of the deposit. The natural cracking, dislocations and inhomogeneities in the rock salt massif can significantly contribute to the intensification of the dilation phenomenon and implicitly to the deformation of the resistance structures and the convergence of the excavations.

All the geomechanical characteristics [11, 12], mentioned above, determine a higher compressibility of the rock salt massif under the action of the tensions developed into the massif, the vertical deformation of the pillars, the convergence of the rooms, transmitted to the surface in the form of the surface subsidence phenomenon.

\section{Tectonics and microtectonics of the deposit}

From a tectonic point of view, the deposits within Slănic perimeter are located in a large Miocene syncline. The Lower and Middle Miocene formations are framed between two major fractures: Audia line and Cosminele fault. The salt that appears in the middle of the syncline is intensely wrinkled, due to the pressure that manifested itself from the direction of Homorâciu spur. Due to the lateral pressures to which the deposit was subjected, there is a tendency of rock salt diapirism in the central-northern area.

From the above synthesis, regarding the tectonics of the deposit, the following conclusions can be drawn: the distribution of geostatic and hereditary stresses into the massif is uneven; due to the lateral pressures during the genesis of the deposit, it is possible that the natural state of stresses to be characterized by some horizontal stresses that tend to at least equal the value of the vertical stresses into the massif; the base of the syncline is marked by a concentration of hereditary stresses in this area; the major faults Audia and Cosminele, following the deformations of the massif generated by the underground mining can be factors of destabilization of the rock masses and of non-uniform transmission of the deformations to the surface.

Regarding the microtectonics, as it was found following the macroscopic and electrometric observations made on the ceilings of Cantacuzino mine, the deposit is strongly marked by cracks and fractures towards its eastern area, with different orientations, geometric and geomechanical characteristics, due to orogenic loads developed from the northeast direction on the deposit, during the formation period. These fractures essentially contribute to the stability of the resistance structures, from Cantacuzino mine and from the Victoria mine, and implicitly to the stability of the surface.

\section{Hydrogeology of the deposit}

In the case of rock salt mines, in addition to the danger of floods, water infiltration into the deposit and into the underground mining excavations poses a significant risk due to the action of dissolving the rock salt massif and compromising the stability of underground resistance structures. Water infiltrations in the subsoil occur on natural fractures or induced by underground mining of rock salt [13].

Moreover, by dissolving the rock salt from the marginal safety pillars, gaps are formed, larger or smaller, which themselves lead to local or more extensive phenomena of surface instability and which overlap with the subsidence phenomena generated by underground mining of rock salt. Hence the complexity of the phenomenon of surface deformation, sometimes combined with landslides. For each landmark of coordinate $(x, y, z)$, in which the deformation of the terrain at a given time $t$ was determined, there is a subsidence (vertical displacement) $W_{(x, y, z, t)}^{\text {total }}$ composed of a displacement generated by the influence of mining excavations $W_{(x, y, z, t)}^{\exp l .}$ and a displacement generated by the dissolution voids $W_{(x, y, z, t)}^{\text {dizolv. }}$, so $W_{(x, y, z, t)}^{\text {total }}=W_{(x, y, z, t)}^{\exp l .}+W_{(x, y, z, t)}^{\text {dizolv }}$ :

From a practical point of view, it is almost impossible to dissociate the two types of subsidence from total subsidence, especially since the volume, shape and spatial position of the dissolution voids cannot be accurately determined. 
From a hydrographic point of view, Slănic perimeter is located on the valley of Slănic brook, which crosses the landform above the deposit, from north to south and is an important source of water for underground infiltrations.

The geological formations within the perimeter were separated, according to their hydrogeological behavior, into three types: permeable formations in which permanent aquifers develop; permeable and semipermeable formations in which seasonal aquifer accumulations develop; impermeable formations devoid of significant aquifer accumulations.

The points where water infiltrations appeared in time in the underground mining works are the following: the coastal mining work; the pumping station from m. 1672 (next to the Green Baths); level I (Victoria mine); shaft 1; shaft 2; shaft 23 August (area 18 - $40 \mathrm{~m}$ ); Principatele Unite mine (Moldova block); Unirea mine (SE pillar 1); car access inclined plane; Cantacuzino mine (car access mining work and strip plan); Cantacuzino shaft (aeration shaft 3).

\section{The effect of explosives detonation on the stability of the excavations and underground structures}

The increase of the mining depth of the rock salt in the case of salt mines from Romania, and implicitly of the extraction level from Slănic Prahova Salt Mine at over 300m obviously determines an amplification of the state of stresses and deformations, accentuated around the underground mining excavations. These phenomena are amplified by the repeated effects of seismic waves generated by systematic detonation, of approx. twice a day, more than $200 \mathrm{~kg}$ of explosive - induced seismic phenomenon, equivalent to a natural earthquake of 4-5 degrees on the Richter scale. As a singular effect, these seismic phenomena could be appreciated as insignificant, but their cumulative effect, over the years and even decades, is a very important one, destroying the integrity of the resistance structures on a depth appreciated at more than $0.6-1.0 \mathrm{~m}$. The only effective solution for solving the stability problems, highlighted above, is to give up the use of explosives to extract the rock salt from the massif, in favor of mechanical cutting with the help of feeders or fellers.

\section{Conclusions}

Victoria Mine (Slănic Prahova Salt Mine) was opened in 1970, where the small rooms and square pillars mining method was applied, with multi-storey levels, separated by safety ceilings with a thickness of $8 \mathrm{~m}$. The activity of the Victoria mine was stopped in 1992, at this mine, the voids resulted from the underground mining of the deposit amount to an area of $922391 \mathrm{~m}^{2}$ and a volume of $7379128 \mathrm{~m}^{3}$. Starting with 1993, south of the old mines, Cantacuzino Mine was opened, where the mining method with small rooms, square pillars and a straight ceiling was applied between the levels V and VII, and starting from level VIII, the same method was applied, but with rooms with vaulted ceilings. As the exploitable reserves at Cantacuzino Mine, located above the level $+200 \mathrm{~m}$, have been depleted, the activity continues below the level $+200 \mathrm{~m}$, starting with the XIV-th level, located under an equalization ceiling.

In the case of Victoria Mine, the landmarks with the highest subsidence are between $93 \mathrm{~mm}$ (landmark RC 40) and $585 \mathrm{~mm}$ (landmark RC 27), with subsidence speeds of $0.35 \mathrm{~mm} / \mathrm{month}$ and $2.23 \mathrm{~mm} / \mathrm{month}$, respectively. For both the prognosis of subsidence and of subsidence speeds, the functions with the best approximation were the linear, logarithmic and power type ones, which highlight a very diverse behavior of the surface deformation phenomena.

In the case of the monitoring area placed under the influence of Cantacuzino mine, it was not possible to make a good estimation of the evolution of the subsidence and subsidence speeds over time, due to the fact that only the last two measurement campaigns were accessed. Therefore, the estimation made only for the last two values could only lead to some linear prognosis functions, acceptable only for a maximum period of 15-20 years.

The main factors that led to the displacement of the surface in the case of the Slănic Prahova Salt Mine, the Victoria and Cantacuzino mines, are: the dimensions of the voids resulting from underground mining, depth of the deposit, geomechanical characteristics of the rock salt deposit and surrounding rocks, tectonics and microtectonics of the deposit, hydrogeology of the deposit, the effect of explosives detonation on the stability of the excavations and underground structures. 


\section{References}

[1] D.P., Marian, 2011

Surface Stability Analysis as Effect of Underground Mining of the Coal Seams with Gentle and Medium Dip from the Jiu Valley Coal Basin (PhD Thesis, University of Petrosani).

[2] B.G.H. Brady, E.T. Brown, 2005

Rock Mechanics for Underground Mining, Third edition (Kluwer Academic Publishers, New York, Springer Science + Business Media, Inc.).

[3] G. Brauner, 1973

Subsidence Due to Underground Mining (US Bureau of Mines, Information Circular 8571)

[4] L. Sanmiquel, M. Bascompta, C. Vintró, T. Yubero, 2018

Subsidence Management System for Underground Mining, Minerals, 8(6), 1-13.

[5] K. Tajduś, 2013

Mining-Induced Surface Horizontal Displacement: the Case of BW Prosper Haniel Mine, Arch. Min. Sci., 58 (4), 10371055.

[6] ***, 1995

Akzo Nobel Salt Inc. Hampton Corners Mine Project. Appendix D.

[7] I. Onica, D.P. Marian, 2016

Applications of the Finite Element Method in the Analysis of Surface Stability and Underground Structures (Universitas Publishing House, Petrosani, 2016) - (in Romanian).

[8] D.P. Marian, I. Onica, M. Georgescu, E. Cozma, et.al., 2019

Study on the stability of constructions and surface in the perimeter of influence of Old Mines (Ocna din Deal and Ocna din Vale), Victoria, Unirea and Cantacuzino according to know existing data (topographic, rheological, geological, hydrogeological, etc.) as well as the deformations of the resistance elements of the underground excavations in Cantacuzino mine, in order to carry out in safe conditions the underground mining activity and protection of the civil and industrial (University of Petrosani, Research Contract no. 186/15.10.2019) - (in Romanian).

[9] C. Hirian, M. Georgescu, 2012

Stability of the Old Salt Mines from Romania - Condition of their Use for Various Fields (Universitas Publishing House, Edition a II-a) - (in Romanian).

[10] G. Herget, (1988)

Stresses in Rock, (Balkema).

[11] M. Milea, et. al., 2009

Study of the physical-mechanical and rheological parameters of the rock salt from Slănic Prahova deposit and resizing the elements of the resistance structures (pillars-ceilings) of the extracted areas (Cantacuzino mine), in order to ensure the overall stability of the area, Stage II / Part 1 - Statistical processing of the data resulting from laboratory tests (SC MINESA-ICPM SA Cluj-Napoca, Research Contract no. 10 848/2011/26.10.2007; Symbol project 49-724-01, 2009) - (in Romanian).

[12] M. Stamatiu, 1959

The Problem of Pillars Design at Rock Salt Mines in Romania (Publishing House of the Academy) - (in Romanian).

[13] A. Ulmeanu, et al., 2014

Geophysical Study: Geoelectric Research for Establishing the Hydrogeological Conditions on the Area of the Rock Salt Deposit from Slănic Prahova, Prahova County (Geological Institute of Romania Bucharest, Contract 320/2307, December 2014).

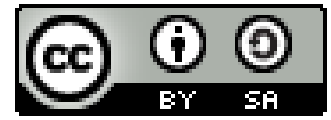

This article is an open access article distributed under the Creative Commons BY SA 4.0 license. Authors retain all copyrights and agree to the terms of the above-mentioned CC BY SA 4.0 license. 